Zeszyty Naukowe Szkoły Głównej Gospodarstwa Wiejskiego

Ekonomika i Organizacja Gospodarki Żywnościowej nr 120, 2017: 55-67

DOI 10.22630/EIOGZ.2017.120.38

Tomasz Siudek, Katarzyna Drabarczyk

Wydział Nauk Ekonomicznych

Szkoła Główna Gospodarstwa Wiejskiego w Warszawie

\title{
Rozwój powiatów województwa mazowieckiego - wymiar ekologiczny
}

\section{Wstęp}

Definicja rozwoju gospodarczego ewaluowała w czasie. Początkowo rozwój ten utożsamiano ze wzrostem gospodarczym. $Z$ literatury przedmiotu wynika, że rozwój gospodarczy jest powiązany z jakościowymi przemianami w rzeczowej, własnościowej i instytucjonalnej sferze gospodarki narodowej. W miarę upływu lat pojęcie rozwoju rozszerzyło swój zakres, obejmując również sferę społeczną, między innymi poziom wykształcenia społeczeństwa, dostęp do kultury, stan opieki zdrowotnej. Przy badaniu rozwoju oprócz wymiarów ekonomicznego i społecznego brany jest pod uwagę aspekt ekologiczny związany ze stanem środowiska naturalnego. Obecnie w strategiach rozwoju krajów, regionów, powiatów czy gmin dominuje podejście zrównoważonego/trwałego rozwoju, w których zakłada się podobne zmiany ilościowe i jakościowe w sferach ekonomicznej, społecznej i ekologicznej.

W badaniu rozwoju duże znaczenie ma wymiar ekologiczny (środowiskowy), który istotnie wpływa na warunki życia ludności. Z punktu widzenia realizacji założeń zrównoważonego rozwoju kluczowe w tym wymiarze jest zachowanie bioróżnorodności oraz wysokiej jakości środowiska przyrodniczego. W tej koncepcji postuluje się o całkowite zaprzestanie lub ograniczenie eksploatacji zasobów nieodnawialnych na rzecz zwiększenia wykorzystania zasobów odnawialnych [Kruk 2015].

Rozwój kraju, regionu lub sektora gospodarki ma wielowymiarowy charakter, a do jego pomiaru wykorzystuje się wiele alternatywnych cech/zmiennych [Siudek 2008, Costanza i in. 2009, Zawojska 2011]. Ze względu na szeroki zakres badań nad rozwojem w niniejszej pracy skupiono się wyłącznie na jego wy- 
miarze ekologicznym ${ }^{1}$. Badania przeprowadzono na powiatach z województwa mazowieckiego, jednego z najbardziej zróżnicowanych wewnątrznie pod względem poziomu rozwoju regionalnego.

\section{Cel, zakres i metody badań}

Głównym celem badań było określenie poziomu rozwoju ekologicznego 42 powiatów województwa mazowieckiego przy wykorzystaniu autorskiego wskaźnika syntetycznego. Badania obejmowały lata 2006-2015 i wykorzystano w nich 420 obserwacje. Zebrane dane pochodziły z Banku Danych Lokalnych GUS. W badaniach wykorzystano 7 zmiennych pierwotnych, takich jak ${ }^{2}$ :

$x_{1}$-emisja zanieczyszczeń gazowych powietrza z zakładów przemysłowych w ciagu roku $\left[\mathrm{t} / \mathrm{km}^{2}\right]$,

$x_{2}$-emisja zanieczyszczeń pyłowych powietrza z zakładów przemysłowych $\mathrm{w}$ ciagu roku $\left[\mathrm{t} / \mathrm{km}^{2}\right]$,

$x_{3}$-ścieki przemysłowe wymagające oczyszczenia, odprowadzone do wód lub ziem w ciagu roku $\left[\mathrm{dm}^{3} / \mathrm{km}^{2}\right]$,

$x_{4}$ - udział powierzchni gruntów leśnych w powierzchni ogółem [\%],

$x_{5}$ - odpady z gospodarstw domowych w ciagu roku [kg/mieszkańca],

$x_{6}-$ ścieki przemysłowe wytworzone $\left[\mathrm{dm}^{3} / \mathrm{km}^{2}\right]$,

$x_{7}$-ścieki komunalne wytworzone $\left[\mathrm{dm}^{3} / \mathrm{km}^{2}\right]$.

Spośród przyjętych zmiennych wyłącznie $x_{4}$ zaliczono do stymulant, a pozostałe zmienne uznano za destymulanty, których wartości zapisano ze znakiem minus. W celu oszacowania wskaźnika syntetycznego rozwoju ekologicznego powiatów województwa mazowieckiego zastosowano analizę czynnikową. Jej istota polegała na przekształceniu liniowym $n$-zmiennych pierwotnych ${ }^{3} X_{i}(i=$ $=1, \ldots, n)$ na $t$ nowych zmiennych wtórnych $U_{k}(k=1, \ldots, t)$, które są wzajemnie nieskorelowane, a suma ich wariancji jest równa sumie wariancji zmiennych pierwotnych $X_{i}$. Zmienne $U_{k}$ nazwane są czynnikami głównymi, a ich wariancja wyjaśnia pewną część zmienności cech pierwotnych, która wyrażana jest przez wartość własną. Kolejne wyodrębnione czynniki główne wyjaśniają coraz mniej zmienności. W celu ich wyodrębnienia w badaniach zastosowano kryterium Ka-

\footnotetext{
${ }^{1}$ Używany w pracy termin rozwój powiatów w wymiarze ekologicznym należy utożsamiać z terminem rozwój ekologiczny powiatów.

${ }^{2}$ Dobór zmiennych pierwotnych do badań uwarunkowany był głównie zasobami informacji o rozwoju powiatów w Polsce w bazie danych lokalnych GUS.

${ }^{3} \mathrm{~W}$ analizie czynnikowej wszystkie zmienne pierwotne były standaryzowane, a zastosowaną techniką rotacji zmiennych wtórnych była technika Varimax. Wszystkie obliczenia statystyczne przeprowadzono za pomocą programu statystycznego Statgraphics.
} 
isera. Za główne czynniki przyjęto te, dla których wartość własna jest większa od 1.

Wartości czynników głównych i wartości wskaźnika syntetycznego rozwoju ekologicznego powiatów województwa mazowieckiego obliczano według równań 1 i 2 :

$$
U_{k}=a_{1 k} x_{1}+a_{2 k} x_{2}+a_{3 k} x_{3}+\ldots a_{n k} x_{n}
$$

gdzie:

$U_{k} \quad$ - wartość $k$-tego czynnika głównego, $k=1,2, \ldots, t$,

$a_{i k} \quad$-oszacowane wagi składowe $i$-tych zmiennych pierwotnych przy $k$-tym czynniku głównym,

$x_{i} \quad$ - wartość $i$-tej zmiennej pierwotnej, $i=1,2, \ldots, n$.

$$
W_{s}=b_{1} U_{1}+b_{2} U_{2}+b_{3} U_{3}+\ldots b_{t} U_{t}
$$

gdzie:

$W_{s}$ - wskaźnik syntetyczny rozwoju ekologicznego powiatów województwa mazowieckiego ${ }^{4}$,

$b_{k} \quad$ - oszacowane wagi składowe $k$-tych czynników głównych, odzwierciedlające określony procent zmienności, $k=1,2, \ldots, t$,

$U_{k} \quad$ - wartość $k$-tego czynnika głównego, $k=1,2, \ldots, t$.

\section{Rozwój ekologiczny w świetle badań empirycznych na świecie}

Rozwój ekologiczny może być oceniany przy wykorzystaniu pojedynczych wskaźników, jak również mierników syntetycznych, agregujących poszczególne zmienne pierwotne, takich jak przykładowo EF (ang. ecological footprint) [Tang $\mathrm{i}$ in. 2017], ESI (ang. environmental sustainability index) [Babcicky 2013], EPI (ang. environmental performance index) [Srebotnjak 2008] czy IIEE (ang. index of intensity of environmental exploitation) [Cieślik 2008]. Z przeglądu literatury wynika, że badania dotyczące rozwoju ekologicznego prowadzone są na poziomach globalnym, krajowym, regionalnym i lokalnym. Wyjaśniają one poziom, zmiany i determinanty rozwoju ekologicznego, jak również jego związek z rozwojem ekonomicznym i społecznym.

Lee i Peng [2014] wskazują, że w latach 2008-2011 wskaźnik EF (ang. ecological footprint) na Tajwanie był wyższy niż w latach 1997-2007, co oznacza pogorszenie stanu środowiska naturalnego. W celu jego poprawy autorzy ci

\footnotetext{
${ }^{4}$ Wraz ze wzrostem wskaźnika syntetycznego wzrasta poziom rozwoju ekologicznego powiatów województwa mazowieckiego i na odwrót.
} 
proponują wprowadzenie przez władze Tajwanu polityki redukcji emisji gazów cieplarnianych i zużycia energii, która pozwoli efektywnie zarządzać zasobami ekologicznymi.

Strien i współautorzy [2016] badając rozwój ekologiczny w Holandii w latach 1990-2014, stwierdzili jego spowolnienie. W badaniach wykorzystali wskaźnik LPI (ang. living planet index), którego wartość oszacowali na podstawie 361 gatunków zwierząt. Podkreślili, że proces pogarszania stanu bioróżnorodności zwierząt można zahamować poprzez wprowadzenie właściwej polityki ochrony środowiska.

Jarita i Afroz [2013] wykorzystując wskaźnik EPI (ang. environmental performance index), stwierdzili, że rozwój gospodarczy przyczynia się do poprawy stanu środowiska naturalnego, a wzrost ludności do jego pogorszenia. Podobne wyniki uzyskała Hrnciarova [1996] dla Słowacji, wykazując, że wraz ze wzrostem gęstości zaludnienia następuje coraz większa degradacja środowiska naturalnego.

El Khanji i Hudson [2016] analizując 177 krajów w latach 1960-2009, wykazali, że jakość wody ma większy wpływ na rozwój gospodarczy niż jej ilość. Duże zanieczyszczenie wody na danym terenie wywołuje nieodwracalne zmiany w ekosystemie. Autorzy stwierdzili, że wzrost gospodarczy w istotnym stopniu może być spowalniany przez zły stan środowiska naturalnego.

McGranahan i Satterthwaite [2002] dowiedli, że wraz ze wzrostem dochodów ludności miast pogarsza się stan ich środowiska naturalnego. Zauważyli, że mieszkańcy miast o dużych dochodach wytwarzają więcej odpadów i dwutlenku węgla $\mathrm{w}$ porównaniu do ludności miast o średnich i małych dochodach. Z kolei według Nevado-Peńy i współautorów [2015] miasta o największym rozwoju ekologicznym i społecznym odznaczają się lepszymi wynikami ekonomicznymi niż pozostałe.

Siudek i Vashchyk [2014] analizując poziom wybranych wskaźników ekologicznych w krajach UE w latach 2000-2012, dowiedli, że najwyższy poziom rozwoju pod względem ekologicznym występował na Łotwie, w Finlandii, Austrii, Szwecji i Estonii, a najniższy - we Francji, w Polsce, na Malcie, w Hiszpanii i Wielkiej Brytanii.

Roszkowska i Karwowska [2014] wykorzystując autorski wskaźnik syntetyczny rozwoju ekologicznego, uzyskały wyniki wskazujące na najwyższy jego poziom w województwach dolnośląskim, kujawsko-pomorskim i warmińsko-mazurskim, a najniższy - w łódzkim, świętokrzyskim i opolskim. Przy opracowaniu wskaźnika syntetycznego autorki wykorzystały takie zmienne pierwotne, jak: zmienność klimatu, zużycie energii, zanieczyszczenie powietrza, zasoby słodkiej wody, użytkowanie gruntów, bioróżnorodność i gospodarowanie odpadami. 
Kusideł i Modranka [2012] badając wszystkie powiaty w Polsce w latach 2004 i 2009, stwierdziły dodatni związek między rozwojem gospodarczym a ładem środowiskowym. Ten ostatni wykazywał najwyższy poziom w południowo-wschodniej Polsce, głównie w powiatach Sanok, Jarosław i Przeworsk.

Paluch [2014] studiując rozwój ekonomiczny i ekologiczny gmin województwa małopolskiego, wykazał, że wraz ze wzrostem poziomu ich rozwoju ekonomicznego wzrasta poziom infrastruktury w zakresie ochrony środowiska i gospodarki wodnej.

\section{Rozwój ekologiczny powiatów województwa mazowieckiego - wyniki badań własnych}

W celu oszacowania poziomu rozwoju powiatów pod względem ekologicznym wykorzystano 7 zmiennych pierwotnych, spośród których przy wykorzystaniu analizy czynnikowej wyodrębniono 2 czynniki główne, które indywidualnie wyjaśniały odpowiednio 55,73 i 19,34\%, a łącznie 75,07\% całkowitej zmienności (tab. 1).

\section{Tabela 1}

Analiza czynnikowa rozwoju ekologicznego powiatów województwa mazowieckiego w latach 2006-2015

\begin{tabular}{|c|c|c|c|}
\hline Czynnik & Wartość własna* & $\begin{array}{c}\text { Procent całkowitej } \\
\text { wariancji }\end{array}$ & $\begin{array}{c}\text { Skumulowany procent } \\
\text { wyjaśnionej wariancji }\end{array}$ \\
\hline 1 & $3,90^{*}$ & 55,73 & 55,73 \\
\hline 2 & $1,35^{*}$ & 19,34 & 75,07 \\
\hline 3 & 0,96 & 13,66 & 88,73 \\
\hline 4 & 0,42 & 5,96 & 94,69 \\
\hline 5 & 0,22 & 3,16 & 97,85 \\
\hline 6 & 0,14 & 2,00 & 99,85 \\
\hline 7 & 0,01 & 0,15 & 100,00 \\
\hline
\end{tabular}

* Wartość własna uznana za istotną zgodnie z kryterium Kaisera.

Źródło: Badania własne.

Największy wpływ na czynnik pierwszy nazwany jako „zanieczyszczenia przemysłowe" wywierały takie zmienne pierwotne, jak: emisja gazowych zanieczyszczeń powietrza z zakładów przemysłowych $\left(x_{1}\right)$ oraz ścieki przemysłowe wymagające oczyszczenia, odprowadzone do wód lub ziem w ciągu roku $\left(x_{3}\right)$. Ładunki czynnikowe tych zmiennych wynosiły odpowiednio 0,9603 i 0,9597 (tab. 2). Na czynnik drugi oznaczony jako „odpady komunalne” najsilniejszy 
Tabela 2

Czynniki decydujące o zróżnicowaniu rozwoju ekologicznego w powiatach województwa mazowieckiego w latach 2006-2015

\begin{tabular}{|l|c|c|}
\hline \multirow{2}{*}{ Zmienne pierwotne } & \multicolumn{2}{|c|}{ Ładunki czynnikowe } \\
\cline { 2 - 3 } & czynnik 1 & czynnik 2 \\
\hline $\begin{array}{l}\text { Emisja gazowych zanieczyszczeń powietrza z zakładów przemy- } \\
\text { słowych w ciagu roku [t/km²] }-x_{1}\end{array}$ & 0,9603 & 0,1428 \\
\hline $\begin{array}{l}\text { Emisja pyłowych zanieczyszczeń powietrza z zakładów przemy- } \\
\text { słowych w ciagu roku [t/km²] }-x_{2}\end{array}$ & 0,9153 & 0,1689 \\
\hline $\begin{array}{l}\text { Ścieki przemysłowe wymagające oczyszczenia, odprowadzone } \\
\left.\text { do wód lub ziem w ciagu roku [dm } / \mathrm{dm}^{2}\right]-x_{3}\end{array}$ & 0,9597 & 0,0857 \\
\hline $\begin{array}{l}\text { Udział powierzchni gruntów leśnych w powierzchni ogółem [\%] } \\
-x_{4}\end{array}$ & $-0,0793$ & 0,4189 \\
\hline $\begin{array}{l}Z \text { Zmieszane odpady zebrane w ciagu roku z gospodarstw domo- } \\
\text { wych [kg/mieszkańca] }-x_{5}\end{array}$ & 0,1559 & 0,8259 \\
\hline Ścieki przemysłowe wytworzone $\left[\mathrm{dm}^{3} / \mathrm{km}^{2}\right]-x_{6}$ & 0,9365 & $-0,0113$ \\
\hline Ścieki komunalne wytworzone $\left[\mathrm{dm}^{3} / \mathrm{km}^{2}\right]-x_{7}$ & 0,3099 & 0,8101 \\
\hline
\end{tabular}

$x_{\mathrm{i}}$ - wartość $i$-tej zmiennej pierwotnej, $i=1,2,3, \ldots, 7 ; U_{k}$-wartość $k$-tego czynnika głównego, $k=1,2$.

Źródło: Badania własne.

wpływ miały odpady z gospodarstw domowych $\left(x_{5}\right)$ i ścieki komunalne $\left(x_{7}\right)$ (ładunki czynnikowe tych zmiennych wynosily odpowiednio 0,8259 i 0,8101 ).

Pod względem wartości czynnika pierwszego najlepsze (czyli generujące najmniej zanieczyszczeń przemysłowych) były powiaty płocki, garwoliński i makowski, a pod względem czynnika drugiego - siedlecki, lipski i radomski (tab. 3). W przypadku obydwu czynników najsłabsze okazały się miasta na prawach powiatu.

Tabela 3

Ranking powiatów województwa mazowieckiego ze względu na poziom rozwoju ekologicznego w latach 2006-2015

\begin{tabular}{|l|c|c|c|c|c|c|}
\hline Powiat & Czynnik 1 & Pozycja & Czynnik 2 & Pozycja & $W_{s}$ & Pozycja \\
\hline \multicolumn{1}{|c|}{1} & 2 & 3 & 4 & 5 & 6 & 7 \\
\hline Białobrzeski & 1,0594 & 13 & 0,3244 & 23 & 0,6531 & 21 \\
\hline Ciechanowski & 0,8168 & 28 & $-0,1040$ & 30 & 0,4351 & 28 \\
\hline Garwoliński & 1,2340 & 2 & 1,0907 & 10 & 0,8986 & 4 \\
\hline Gostyniński & 1,0605 & 12 & 0,7009 & 15 & 0,7266 & 16 \\
\hline Grodziski & 0,8165 & 29 & $-0,3358$ & 32 & 0,3901 & 30 \\
\hline Grójecki & 0,7534 & 32 & $-0,0418$ & 27 & 0,4118 & 29 \\
\hline Kozienicki & $-0,8165$ & 38 & 0,6429 & 16 & $-0,3307$ & 37 \\
\hline
\end{tabular}


Tabela 3, cd.

\begin{tabular}{|c|c|c|c|c|c|c|}
\hline 1 & 2 & 3 & 4 & 5 & 6 & 7 \\
\hline Legionowski & 0,6443 & 34 & $-0,1235$ & 31 & 0,3352 & 33 \\
\hline Lipski & 1,0611 & 11 & 1,8917 & 2 & 0,9572 & 2 \\
\hline Łosicki & 0,9313 & 21 & 1,6440 & 5 & 0,8370 & 8 \\
\hline Makowski & 1,2128 & 3 & 0,3808 & 21 & 0,7495 & 12 \\
\hline Miński & 0,8837 & 25 & 0,5543 & 17 & 0,5997 & 22 \\
\hline Mławski & 0,7850 & 30 & 0,4743 & 19 & 0,5292 & 25 \\
\hline Nowodworski & 0,8864 & 24 & $-0,0577$ & 28 & 0,4828 & 26 \\
\hline Ostrołęcki & 1,0020 & 17 & 1,6577 & 4 & 0,8790 & 6 \\
\hline Ostrowski & 0,8960 & 23 & 0,8097 & 14 & 0,6559 & 20 \\
\hline Otwocki & 0,6330 & 35 & 0,0328 & 26 & 0,3591 & 32 \\
\hline Piaseczyński & 0,7729 & 31 & $-0,5608$ & 33 & 0,3223 & 34 \\
\hline Płocki & 1,2443 & 1 & 0,3282 & 22 & 0,7569 & 11 \\
\hline Płoński & 0,9949 & 19 & $-0,1030$ & 29 & 0,5345 & 24 \\
\hline Pruszkowski & 0,3976 & 36 & $-0,5902$ & 34 & 0,1075 & 36 \\
\hline Przasnyski & 0,9167 & 22 & 1,1602 & 8 & 0,7353 & 15 \\
\hline Przysuski & 1,1146 & 7 & 1,3884 & 6 & 0,8897 & 5 \\
\hline Pułtuski & 0,9748 & 20 & 1,0581 & 11 & 0,7479 & 13 \\
\hline Radomski & 1,0304 & 16 & 1,7266 & 3 & 0,9082 & 3 \\
\hline Siedlecki & 1,1104 & 9 & 2,0550 & 1 & 1,0163 & 1 \\
\hline Sierpecki & 1,1087 & 10 & 0,2407 & 25 & 0,6644 & 19 \\
\hline Sochaczewski & 0,8774 & 27 & $-0,6348$ & 36 & 0,3661 & 31 \\
\hline Sokołowski & 1,1133 & 8 & 1,0161 & 12 & 0,8169 & 10 \\
\hline Szydłowiecki & 1,1484 & 5 & 0,3113 & 24 & 0,7002 & 18 \\
\hline Warszawski Zachodni & 0,7083 & 33 & $-1,4142$ & 37 & 0,1212 & 35 \\
\hline Węgrowski & 1,0440 & 15 & 1,2953 & 7 & 0,8323 & 9 \\
\hline Wołomiński & 0,8836 & 26 & 0,4567 & 20 & 0,5807 & 23 \\
\hline Wyszkowski & 1,0010 & 18 & 0,8136 & 13 & 0,7152 & 17 \\
\hline Zwoleński & 1,1651 & 4 & 1,1151 & 9 & 0,8650 & 7 \\
\hline Żuromiński & 1,1367 & 6 & 0,5341 & 18 & 0,7368 & 14 \\
\hline Żyrardowski & 1,0586 & 14 & $-0,6189$ & 35 & 0,4702 & 27 \\
\hline m. Ostrołęka & $-21,8396$ & 42 & $-4,0427$ & 41 & $-12,9527$ & 42 \\
\hline m. Płock & $-8,0731$ & 41 & $-3,2194$ & 40 & $-5,1217$ & 41 \\
\hline m. Radom & $-0,4915$ & 37 & $-2,5462$ & 38 & $-0,7664$ & 38 \\
\hline m. Siedlce & $-1,0542$ & 39 & $-2,6505$ & 39 & $-1,1001$ & 39 \\
\hline m. Warszawa & $-2,2029$ & 40 & $-6,6599$ & 42 & $-2,5158$ & 40 \\
\hline
\end{tabular}

$W_{s}$ - wskaźnik syntetyczny.

Źródło: Badania własne. 
Poza wyodrębnieniem czynników głównych do pomiaru rozwoju ekologicznego powiatów województwa mazowieckiego zastosowano wskaźnik syntetyczny. Na podstawie jego wartości stwierdzono, że najwyższy poziom rozwoju ekologicznego wystąpił w następujących powiatach: siedleckim, lipskim, radomskim, garwolińskim, przysuskim, ostrołęckim i zwoleńskim, a najniższy - w miastach na prawach powiatu oraz w powiecie kozienickim. Należy również podkreślić, że powiaty graniczące z miastem Warszawa (piaseczyński, pruszkowski, otwocki, warszawski zachodni i legionowski) odznaczały się relatywnie niskim poziomem rozwoju ekologicznego.

$\mathrm{Z}$ tabeli 4 wynika, że największy wzrost wskaźnika rozwoju w wymiarze ekologicznym w latach 2006-2015 wystapił w powiecie piaseczyńskim (o 88\%), a największy jego spadek w powiatach sochaczewskim (o 62\%) i legionowskim (o 61\%). W badanym okresie różnica między powiatami o największej i najmniejszej wartości wskaźnika syntetycznego pomniejszyła się. W 2006 roku luka ta wynosiła 16,26, a w 2015 roku - 11,77, co wskazuje na złagodzenie dysproporcji ekologicznych między nimi. W 2006 roku najwyższym poziomem rozwoju w wymiarze środowiskowym charakteryzował się powiat siedlecki, a w 2015 roku - powiat lipski. W obu latach najniżej w rankingu powiatów pod tym względem uplasowało się miasto Ostrołęka, w którym odnotowano bardzo dużą emisję gazowych zanieczyszczeń powietrza z zakładów przemysłowych. Mimo że w przypadku tego powiatu między 2006 a 2015 rokiem nastapił największy spośród wszystkich powiatów województwa mazowieckiego przyrost wskaźnika syntetycznego (o 4,4), nie był on na tyle wystarczający, aby awansować w rankingu.

Uwzględniając zmianę kolejności w rankingu powiatów w 2015 roku w stosunku do 2006 roku, największą poprawę pozycji osiągnął powiat piaseczyński (o 14 miejsc). Główny wpływ na to miała 15-krotna redukcja emisji gazowych zanieczyszczeń powietrza z lokalnych zakładów przemysłowych. Najbardziej w rankingu spadł powiat mławski (o 21 miejsc), mimo tego, że spośród 7 charakteryzujących go zmiennych pierwotnych tylko w przypadku 3 nastapiło nieznaczne zmniejszenie ich wartości. Wynika z tego, że sama zmiana pozycji rankingowych nie musi oznaczać polepszenia lub pogorszenia stanu ekologicznego w badanym powiecie, ale świadczy ona o wolniejszym bądź szybszym tempie rozwoju w odniesieniu do pozostałych powiatów. Kilka powiatów województwa mazowieckiego (kozienicki, m. Warszawa, m. Płock i m. Ostrołęka) zajmowało niezmienione pozycje w rankingu we wszystkich latach badanego okresu. 
๑ 10

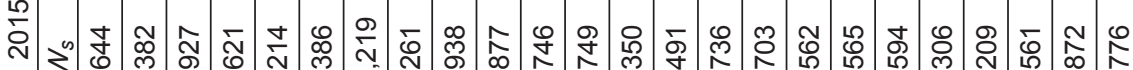

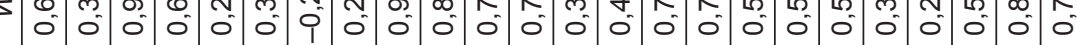

ด ำ

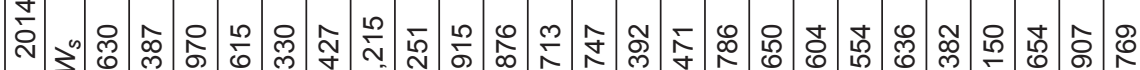

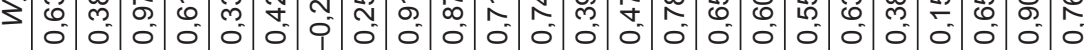

ఎ స পுల m

实山

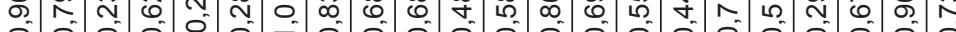

$\stackrel{8}{2}$

๑ ลิ m ㄴ.

\&

స̃

$\frac{\sqrt{0}}{\frac{\pi}{0}}$

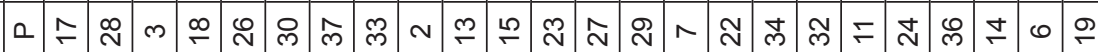

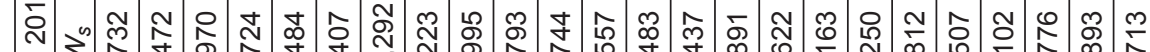

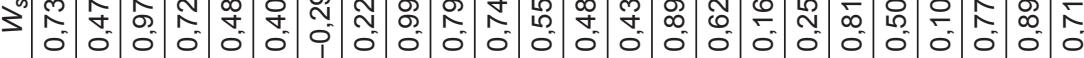

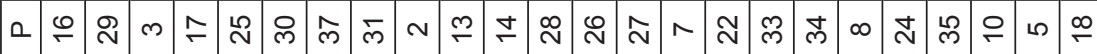
은

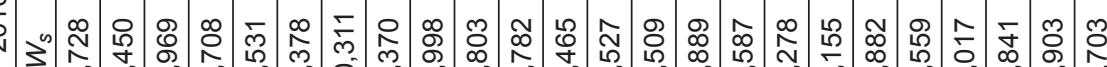

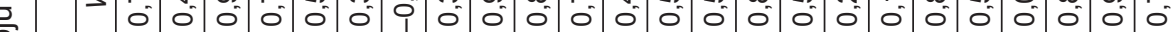

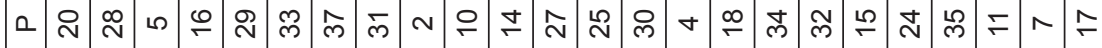
ह 8

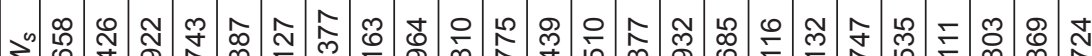

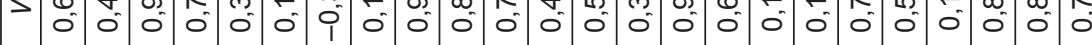

๑ ลิ

రृ

穴 $\frac{\sqrt{3}}{\mathrm{~s}}$

a ป N

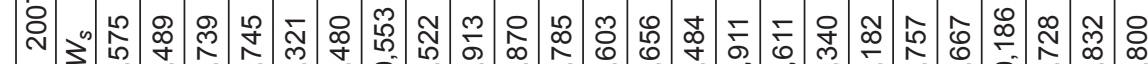

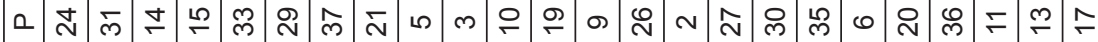

\begin{tabular}{|c|c|c|c|c|c|c|c|c|c|c|c|c|c|c|c|c|c|c|c|c|c|}
\hline $3^{\infty}$ & $\left|\begin{array}{l}\mathbb{N} \\
0 \\
0 \\
0\end{array}\right|$ & $\mid \begin{array}{l}0 \\
0 \\
0 \\
0 \\
0\end{array}$ & $\mid \begin{array}{l}8 \\
0 \\
0 \\
0\end{array}$ & $\mid \begin{array}{l}0 \\
0 \\
0 \\
0 \\
0\end{array}$ & 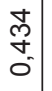 & $\begin{array}{l}0 \\
0 \\
0 \\
0 \\
0\end{array}$ & $\begin{array}{c}0 \\
0 \\
0 \\
0 \\
1\end{array}$ & \begin{tabular}{l|l}
0 & \\
$\vdots$ & 0 \\
0 & 0
\end{tabular} & 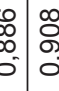 & $\begin{array}{l}0 \\
\end{array}$ & $\mid \begin{array}{l}1 \\
0 \\
0 \\
0\end{array}$ & \begin{tabular}{|l|} 
\\
0 \\
$\infty$ \\
0 \\
0
\end{tabular} & \begin{tabular}{|c|c}
$\infty$ & \\
0 \\
0 \\
0 \\
0 \\
0
\end{tabular} & & 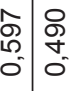 & $\begin{array}{l}\bar{\delta} \\
\bar{p} \\
0 \\
0\end{array}$ & $\mid \begin{array}{c}\mathbb{M} \\
\infty \\
0 \\
0\end{array}$ & \begin{tabular}{l|}
$R$ \\
0 \\
0 \\
0
\end{tabular} & & $\begin{array}{l}0 \\
0 \\
0 \\
0\end{array}$ & \\
\hline & 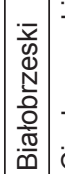 & 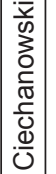 & 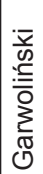 & 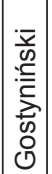 & 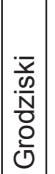 & 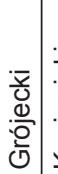 & 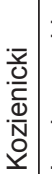 & 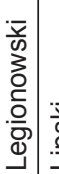 & $\begin{array}{l}\frac{\mathrm{v}}{\mathrm{o}} \\
\text { ل्र }\end{array}$ & 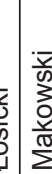 & $\begin{array}{l}\frac{\bar{v}}{\omega} \\
: \stackrel{\equiv}{\sum} \\
\sum\end{array}$ & 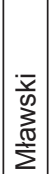 & 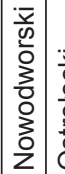 & 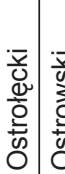 & 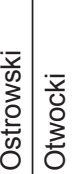 & 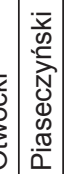 & \begin{tabular}{|} 
\\
$\frac{\bar{y}}{0}$ \\
$\frac{0}{0}$ \\
\end{tabular} & $\begin{array}{l} \\
\frac{\bar{v}}{0} \\
\frac{0}{0} \\
\frac{0}{0} \\
\frac{0}{\alpha}\end{array}$ & $\begin{array}{l}\frac{\bar{v}}{0} \\
3 \\
0 \\
\frac{1}{N} \\
0 \\
\frac{2}{2} \\
0\end{array}$ & 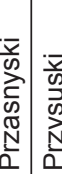 & 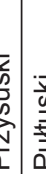 \\
\hline
\end{tabular}




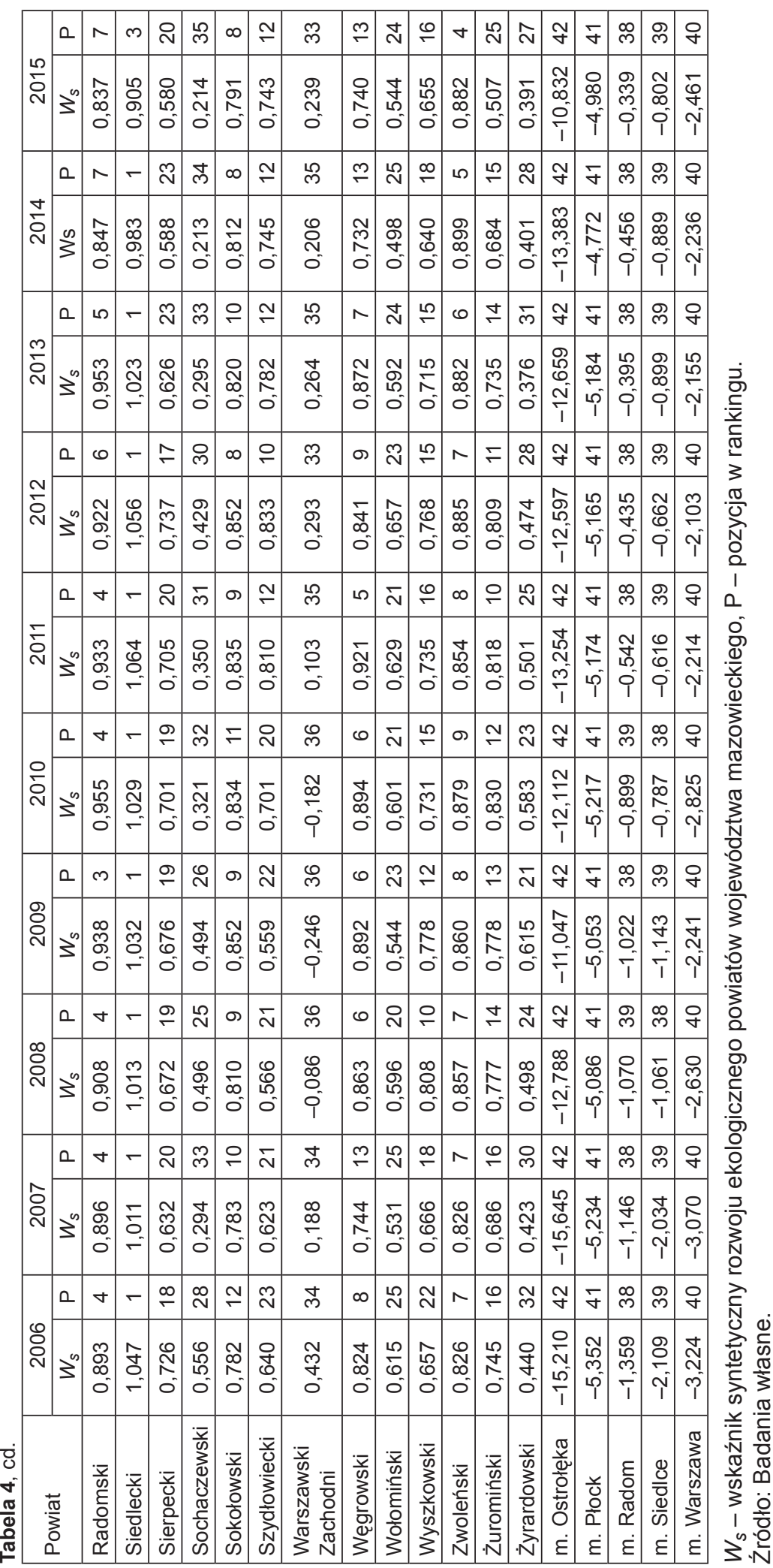




\section{Podsumowanie}

1. Z przeglądu literatury wynika, że rozwój ekologiczny jest uwarunkowany wieloma czynnikami, dlatego wydaje się, że przy mierzeniu jego poziomu powinno wykorzystywać się wielowymiarowe wskaźniki syntetyczne, dzięki którym możliwe jest ustalenie pozycji konkurencyjnej poszczególnych powiatów na tle innych powiatów województwa mazowieckiego.

2. W wyniku badań własnych przeprowadzonych przy zastosowaniu analizy czynnikowej stwierdzono, że głównymi determinantami rozwoju powiatów województwa mazowieckiego pod względem ekologicznym (środowiskowym) są: emisja gazowych zanieczyszczeń powietrza z zakładów przemysłowych oraz ścieki przemysłowe odprowadzone do wód lub ziem (czynnik 1), jak też odpady zebrane z gospodarstw domowych i ścieki komunalne (czynnik 2).

3. Na podstawie obliczonych wskaźników syntetycznych dla poszczególnych powiatów można uznać, że najwyższy średni poziom rozwoju w wymiarze ekologicznym w latach 2006-2015 wystapił w powiatach siedleckim, lipskim i radomskim, a najniższy - w powiecie kozienickim i miastach na prawach powiatu (m. Ostrołęka, m. Płock, m. Warszawa, m. Siedlce, m. Radom). W badanym okresie zmniejszyło się zróżnicowanie poziomu rozwoju ekologicznego między powiatami województwa mazowieckiego.

4. Analiza zmian wartości wskaźnika syntetycznego w latach 2006-2015 wskazuje, że największy jego wzrost wystapił w powiecie piaseczyńskim, a największy spadek w powiatach sochaczewskim i legionowskim. W ponad połowie badanych powiatów wartości tych wskaźników się zmniejszyły.

5. Pomijając miasta na prawach powiatów, należy stwierdzić, że największy rozwój ekologiczny odnotowano w powiatach o charakterze wiejskim/rolniczym, a najmniejszy - w powiatach bardziej zurbanizowanych.

6. Mierniki rozwoju ekologicznego powinny być stale udoskonalane, aby jak najbardziej odzwierciedlać rzeczywisty stan środowiska naturalnego, a tym samym warunki życia ludności. Wiarygodne indeksy rozwoju ekologicznego mogą stanowić cenne źródło informacji dla jednostek samorządu terytorialnego w prowadzeniu polityki ekologicznej w krótkim i długim okresie.

\section{Literatura}

BABCICKY F., 2013: Rethinking the Foundations of Sustainability Measurement: The Limitations of the Environmental Sustainability Index (ESI), Social Indicators Research 113 (1), 133-157. 
CIEŚLIK E., 2008: Wybrane alternatywne sposoby mierzenia rozwoju gospodarczego, Equilibrium 1-2 (1), 145-160.

COSTANZA R., HART M., POSNER S., TALBERTH J., 2009: Beyond GDP: The Need for New Measures of Progress, The Pardee Papers 4, Boston University, Boston.

el KHANIJ S., HUDSON J., 2016: Water Utilization and Water Quality in Endogenous Economic Growth, Environment and Development Economics 21 (5), 626-648.

HRNCIAROVA T., 1996: Ecological Assumptions for Sustainable Development of Slovakia, Ecology (Bratislava) 15 (2), 207-224.

JARITA D., AFROZ R.., 2013: Modeling Environmental Performance and Economic Development, International Journal of Trade, Economics and Finance 4 (6), 384-387.

KRUK H., 2015: Metody pomiaru i oceny wymiaru ekologicznego rozwoju równoważonego na poziomie krajowym i ponadnarodowym, Ekonomia i Środowisko 4 (55), 26 -42.

KUSIDEŁ E., MODRANKA E., 2012: Analiza przestrzennego zróżnicowania powiatów pod względem wpływu rozwoju ekonomicznego na ład ekologiczny, [w:] A. Pawłowska, Z. Rykiel (red.), Region i regionalizm w socjologii i politologii, Wydawnictwo Uniwersytetu Rzeszowskiego, Rzeszów.

LEE Y.J., PENG L.P. 2014: Taiwan's Ecological Footprint (1994-2011), Sustainability 6, 6170-6187.

McGRANAHAN G., SATTERTHWAITE D., 2002: The Environmental Dimensions of Sustainable Development for Cities, Geography 87 (3), 213-226.

NEVADO-PEŃA D., LÓPEZ-RUIZ V.R., ALFARO-NAVARRO J.L., 2015: The Effects of Environmental and Social Dimensions of Sustainability in Response to the Economic Crisis of European Cities, Sustainability 7 (7), 8255-8269.

PALUCH Ł., 2014: Zróżnicowanie poziomu rozwoju gmin wiejskich województwa matopolskiego w wymiarze gospodarczym i ekologicznym, Roczniki Naukowe Stowarzyszenia Ekonomistów Rolnictwa i Agrobiznesu 16 (6), 381-386.

ROSZKOWSKA E., KARWOWSKA R., 2014: Wielowymiarowa analiza poziomu zrównoważonego rozwoju województw Polski w 2010 roku, Zeszyty Naukowe Politechniki Białostockiej. Ekonomia i Zarządzanie 6 (1), 9-37.

SIUDEK T., 2008: Wplyw kredytów rolniczych udzielanych przez banki spółdzielcze na rozwój rolnictwa w Polsce, Zeszyty Naukowe Szkoły Głównej Gospodarstwa Wiejskiego w Warszawie. Ekonomika i Organizacja Gospodarki Żywnościowej 66, 37-47.

SIUDEK T., VASHCHYK M., 2014: Ecological Development of Rural Areas in the European Union Member States in 2000-2012, Zeszyty Naukowe Szkoły Głównej Gospodarstwa Wiejskiego. Problemy Rolnictwa Światowego 14 (4), 194-204.

SREBOTNJAK T., 2008: Environmental Performance Index, [w:] E.L. Melnick, B.S. Everitt (red.), Encyclopedia of Quantitative Risk Analysis and Assessment, John Wiley \& Sons, Hoboken, New Jersey.

STRIEN A., GMELIG MEYLING A., HERDER J., HOLLANDER H., KALKMAN V., POOT M., TURNHOUT S., HOORN B., LIEMPT W., SWAAV C., TURNHOUT C., VERWEIJ R., OERLEMANS N., 2016: Modest Recovery of Biodiversity in a Western European Country: The Living Planet Index for the Netherlands, Biological Conservation 200, 44-50.

TANG J., CHEN Z., FANG J., 2017: Application of Ecological Footprint, Asian Agricultural Research 9 (3), 57-60. 
ZAWOJSKA A., 2011: Looking Beyond the Traditional Concept of Economic Growth: Alternative Meanings and Measures of Nations 'Economic and Social Progress, Regional and Business Studies 3 (1), 339-352.

\section{Abstrakt}

Głównym celem artykułu jest określenie poziomu rozwoju ekologicznego powiatów województwa mazowieckiego przy wykorzystaniu oryginalnego wskaźnika syntetycznego, do którego konstrukcji wykorzystano analizę czynnikową. Z przeprowadzonych badań wynika, że w latach 2006-2015 pod względem ekologicznym najbardziej rozwinięte były powiaty siedlecki, lipski i radomski, a najsłabiej - kozienicki i miasta na prawach powiatu (w tym Warszawa). Dysproporcje rozwojowe między powiatami Mazowsza w tym czasie uległy zmniejszeniu.

Słowa kluczowe: rozwój ekologiczny, wskaźnik syntetyczny, powiaty, województwo mazowieckie, Polska

\section{Ecological development of the Mazovia counties}

\section{Abstract}

The main aim of this paper is to determine the level of ecological development of the Poland's Mazovia counties (poviats) on the basis of the original synthetic index constructed with the use of factor analysis. According to the obtained results, in the years 2006-2015, the highest level of ecological development was achieved by such counties, as: Siedlecki, Lipski and Radomski, while the lowest one in Kozienicki county and towns with county rights (including Warsaw). The development disparities between the Mazovia poviats have decreased over this period.

Key words: ecological development, synthetic index, counties, Mazovia region, Poland 
